Original Paper

\title{
Peningkatan Keterampilan Proses Melalui Penerapan Model Pembelajaran Penemuan (Discovery Learning) Pada Siswa Kelas XI MIPA-3
}

\author{
Wiwik Herawati ${ }^{{ }^{*}}$ \\ ${ }^{1}$ Sekolah Menegah Atas Negeri 1 Mataram, Kota Mataram, Nusa Tenggara Barat, Indonesia
}

DOI: https://doi.org/10.29303/jcar.v3i2.894

*Corresponding Author:

Wiwik Herawati, Sekolah

Menegah Atas Negeri 1

Mataram, Kota Mataram,

Nusa Tenggara Barat,

Indonesia.

Email:

wiwikherawati91@yahoo.co.id

\begin{abstract}
Abstrak: Penelitian tindakan kelas ini bertujuan untuk meningkatkan keterampilan proses siswa kelas XI MIA-3 pada materi Laju Reaksi tahun pelajaran 2019/2020. Penelitian ini dilakukan melalui 2 siklus. Data yang dikumpulkan terdiri dari data kuantitatif dan data kualitatif. Data kuantitatif diperoleh dari hasil pengamatan diolah dengan menggunakan deskripsi persentase. Nilai yang diperoleh siswa dirata-rata untuk menemukan pencapaian keterampilan proses. Data kualitatif diperoleh dari observasi pelaksanaan pembelajaran, data diklasifikasikan berdasarkan aspek-aspek yang dijadikan fokus analisis. Hasil penelitian menunjukan bahwa model pembelajaran penemuan (Discovery Learning) yang di terapkan pada pembelajaran Kimia pada materi Laju Reaksi terbukti dapat meningkatkan keterampilan proses siswa yang mencakup aktivitas menggunakan alat, mengumpulkan data, mengolah dan menganalisis data, menyimpulkan, serta membuat laporan. Terjadi peningkatan nilai rata-rata keterampilan proses dari 84 pada siklus I menjadi 87 pada siklus II. Sehingga pembelajaran Kimia dengan model pembelajaran penemuan (Discovery Learning) terbukti mampu meningkatkan keterampilan proses siswa.
\end{abstract}

Kata kunci: Metode Pemberian Tugas (Resitasi); Media Visual; Hasil Belajar

\section{Pendahuluan}

Tujuan pendidikan adalah untuk mengembangkan dan membentuk watak serta peradaban bangsa yang bermartabat dalam rangka mencerdaskan kehidupan bangsa, bertujuan untuk berkembangnya potensi siswa agar menjadi manusia beriman dan bertaqwa kepada Tuhan Yang Maha Esa, berahlak mulia, sehat, berilmu, cakap, kreatif, mandiri, serta menjadi warga negara yang demokratis dan bertanggung jawab (Undang-Undang No. 20 Tahun 2003 tentang Sistem Pendidikan Nasional). Pendidikan ditujukan untuk mengembangkan potensi-potensi siswa, sikap, serta keterampilan yang dapat digunakan dalam menjalani hidup di masyarakat, bangsa dan Negara jawab (Undang-Undang No. 20 Tahun 2003 tentang Sistem Pendidikan Nasional).

Ilmu Pengetahuan Alam merupakan salah satu mata pelajaran yang sangat penting dalam kurikulum sekolah, seharusnya dapat diajarkan pada siswa secara asyik dan menyenangkan karena mata pelajaran IPA sangat berhubungan dengan kehidupan sehari-hari. Akan tetapi, kenyataannya sangat berlainan. Hal ini dimungkinkan karena salah satu penyebabnya adalah penggunaan model pembelajaran yang 
kurang tepat oleh guru dalam mengajar. Guru lebih banyak mengajarkan konsep-konsep materi pelajaran melalui transfer knowledge dan pemberian contoh yang cenderung dihafal siswa sehingga tidak membentuk konsep yang benar. Pembelajaran seperti ini tentu menciptakan suasana kelas yang kaku, monoton, dan membosankan.

Pembelajaran IPA tidak hanya menyampaikan informasi (fakta) dan pemahaman materi saja namun juga memperhatikan pengembangan kemampuan yang lainnya seperti kemampuan menggunakan alat, mengurai, merangkai, memodifikasi, dan membuat suatu produk, bahkan sampai pada pengembangan sikap spiritual dan social (Sapriati, 2004). Dengan demikian, perlu adanya peran guru dalam menentukan model pembelajaran yang tepat, dimana tidak hanya berpengaruh terhadap aspek pengetahuan saja, tetapi dapat juga berpengaruh terhadap sikap dan keterampilan.

Proses belajar merupakan hasil yang kompleks, siswalah yang menentukan terjadi atau tidak terjadi belajar (Dimyati dan Mudjiono, 2006). Guru berfungsi sebagai pembimbing dan pengarah, sedangkan yang menggerakkan proses tersebut harus datang dari siswa. Dengan demikian, seorang guru perlu menerapkan sebuah pendekatan yang mengarahkan siswa untuk berperan secara aktif dan menggali potensi yang ada pada dirinya sendiri, sehingga siswa mampu mengembangkan keterampilan seperti mengobservasi, mengklasifikasi, memprediksi, mengukur, menyimpulkan, dan mengkomunikasikan.

Berdasarkan observasi awal yang dilakukan oleh peneliti masih dijumpai masalah dalam kegiatan belajar mengajar Kimia di SMA Negeri 1 Mataram terutama kelas XI MIPA-3. Hal tersebut dapat diketahui berdasarkan hasil pengamatan terlihat aktivitas keterampilan melakukan pengamatan, membuat perencanaan, mengumpulkan data, serta membuat laporan belum maksimum. Hal ini dikarenakan beberapa faktor, diantaranya adalah terbawa budaya lama yaitu proses pembelajaran yang masih berpusat pada guru sehingga aktivitas yang berkaitan dengan keterampilan belum berkembang secara optimal, beberapa siswa masih belum melakukan pengamatan menggunakan panca indera yang sesuai.

Pembelajaran yang menekankan pada pembelajaran siswa aktif dalam menemukan konsep sendiri diantaranya adalah metode discovery (Kemendikbud, 2013) Pembelajaran penemuan (discovery learning) merupakan suatu model pembelajaran yang dikembangkan oleh J. Bruner berdasarkan pada pandangan kognitif tentang pembelajaran dan prinsip prinsip konstruktivis (Kemendikbud, 2013). Siswa belajar melalui keterlibatan aktif dengan konsep-konsep dan prinsip-prinsip, dan guru mendorong siswa untuk mendapatkan pengalaman dengan melakukan kegiatan yang memungkinkan mereka menemukan konsep dan prinsip prinsip untuk diri mereka sendiri (Slavin, 2005)

Pembelajaran penemuan (Discovery) membagi siswa ke dalam kelompok-kelompok kecil dan diarahkan untuk mempelajari materi pelajaran yang telah ditentukan. Tujuan dibentuknya kelompok kooperatif adalah untuk memberikan kesempatan kepada siswa agar dapat terlibat secara aktif dalam proses berpikir dan dalam kegiatan-kegiatan belajar. Dalam hal ini sebagian besar aktifitas pembelajaran berpusat pada siswa, yakni mempelajari materi pelajaran serta berdiskusi dan bertukar pikiran dengan temannya yang lebih mampu untuk memecahkan masalah. Sintak Pembelajaran Penemuan (Discovery Learning) terlihat pada Tabel 1. 
Tabel 1. Sintak Pembelajaran Penemuan (Discovery Learning)

\begin{tabular}{|c|c|}
\hline Tahapan & Deskripsi \\
\hline $\begin{array}{l}\text { Tahap I } \\
\text { Stimulation }\end{array}$ & $\begin{array}{l}\text { menyediakan kondisi interaksi belajar yang dapat mengembangkan dan membantu } \\
\text { siswa dalam mengeksplorasi bahan berupa penyajian gambar/ video yang } \\
\text { berkaitan dengan topic }\end{array}$ \\
\hline $\begin{array}{l}\text { Tahap II } \\
\text { Problem Statement }\end{array}$ & $\begin{array}{l}\text { memberi kesempatan kepada siswa untuk mengidentifikasi sebanyak mungkin } \\
\text { agenda-agenda masalah yang relevan dengan bahan pelajaran, kemudian salah } \\
\text { satunya dipilih dan dirumuskan dalam bentuk hipotesis (jawaban sementara atas } \\
\text { pertanyaan masalah) }\end{array}$ \\
\hline $\begin{array}{l}\text { Tahap III } \\
\text { Data Collecting }\end{array}$ & $\begin{array}{l}\text { memberi kesempatan kepada para siswa untuk mengumpulkan informasi } \\
\text { sebanyak-banyaknya yang relevan untuk membuktikan benar atau tidaknya } \\
\text { hipotesis. }\end{array}$ \\
\hline $\begin{array}{l}\text { Tahap IV } \\
\text { Data Processing }\end{array}$ & $\begin{array}{l}\text { Merupakan kegiatan mengolah data dan informasi yang telah diperoleh para siswa } \\
\text { baik melalui wawancara, observasi, dan sebagainya, lalu ditafsirkan. Semua } \\
\text { informai hasil bacaan, wawancara, observasi, dan sebagainya, semuanya diolah, } \\
\text { diacak, diklasifikasikan, ditabulasi, bahkan bila perlu dihitung dengan cara tertentu } \\
\text { serta ditafsirkan pada tingkat kepercayaan tertentu }\end{array}$ \\
\hline $\begin{array}{l}\text { Tahap V } \\
\text { Verification }\end{array}$ & $\begin{array}{l}\text { Siswa melakukan pemeriksaan secara cermat untuk membuktikan benar atau } \\
\text { tidaknya hipotesis yang ditetapkan tadi dengan temuan alternatif, dihubungkan } \\
\text { dengan hasil data processing. Peserta didik membandingkan hasil diskusi antar } \\
\text { kelompok }\end{array}$ \\
\hline $\begin{array}{l}\text { Tahap VI } \\
\text { Generalization }\end{array}$ & $\begin{array}{l}\text { Proses menarik sebuah kesimpulan yang dapat dijadikan prinsip umum dan } \\
\text { berlaku untuk semua kejadian atau masalah yang sama, dengan memperhatikan } \\
\text { hasil verifikasi }\end{array}$ \\
\hline
\end{tabular}

Berdasarkan uraian latar belakang diatas peneliti terdorong untuk melakukan penelitian dengan judul " Peningkatan Keterampilan Proses Siswa Kelas XI MIPA-3 Melalui Penerapan Model Pembelajaran Penemuan (Discovery Learning) pada Materi Laju Reaksi Tahun Pelajaran 2019/2020 “

\section{Metode}

Penelitian ini mengambil lokasi di SMA Negeri 1 Mataram yang beralamat di Jalan Pendidikan No. 21 Mataram. Subyek dalam penelitian ini adalah siswa kelas XI MIPA-3 tahun pelajaran 2019/2020. Adapun jumlah siswa sebagai subyek penelitian adalah 34 siswa, yang terdiri 16 siswa perempuan dan 18 siswa laki-laki. Penelitian Tindakan Kelas dilaksanakan dari tanggal 30 September sampai dengan 12 Oktober 2019.

Prosedur penelitian tindakan ini terdiri dari 2 siklus, dengan masing-masing siklus terdiri atas 4 tahap yaitu perencanaan tindakan, pelaksanaan tindakan, observasi dan evaluasi serta analisis dan refleksi. Siklus I terdiri atas 2 pertemuan, sedang siklus II terdiri atas 2 pertemuan.

Untuk memperoleh data yang akurat dalam penelitian diperlukan instrumen yang sesuai dengan tujuan yang ingin dicapai. Adapun instrumen yang digunakan dalam penelitian ini meliputi: (1) Instrumen Penilaian Kinerja/praktik; (2) Lembar Observasi yang dirancang peneliti untuk mengetahui keterlaksanakan Rancangan Pelaksanaan Pembelajaran (RPP) dalam proses pembelajaran. Observasi dilaksanakan pada saat kegiatan pembelajaran berlangsung.

Teknik tes digunakan untuk mengukur kemampuan siswa dalam menguasai materi yang telah disampaikan. Teknik non tes digunakan untuk mengetahui keterlaksanakan Rancangan Pelaksanaan Pembelajaran (RPP) dan untuk mengetahui keterampilan proses siswa dalam pembelajaran. Data yang diperoleh dengan menggunakan teknik ini adalah data kualitatif. Data ini diperoleh 
dengan cara melakukan observasi secara langsung pada saat kegiatan pembelajaran.

Data hasil observasi dianalisis dengan Menghitung prosentase pencapaian keterampilan proses siswa pada setiap aspek dengan menggunakan rumus:

$\mathrm{PP}=\frac{S P}{S S} \times 100 \%$

Keterangan:

$\mathrm{PP}=$ prosentase pencapaian

$\mathrm{SP}=$ jumlah skor yang diperoleh siswa

SS = jumlah skor seluruhnya

Untuk menentukan kategori pencapaian

keterampilan proses siswa digunakan acuan berikut:

$\begin{array}{ll}90 \%-100 \% & \text { : Sangat Baik (SB) } \\ 80 \%-89 \% & \text { : baik (B) } \\ 70 \%-79 \% & \text { : cukup (C) } \\ \text { dibawah } 70 \% & \text { : kurang (K) }\end{array}$

Indikator keberhasilan penelitian ini dapat dilihat dar adanya peningkatan Keterampilan proses siswa dalam pembelajaran dapat dilihat dari pencapaian prosentase keterampilan proses siswa yaitu $\geq 80 \%$ untuk setiap bentuk keterampilan proses.

\section{Hasil dan Pembahasan}

Menurut Hosnan et al., (2014) model pembelajaran Discovery merupakan model pembelajaran berdasarkan pandangan kontruktivisme. Model Discovery menekankan pentingnya pemahaman struktur atau ide-ide penting terhadap suatu disiplin ilmu melalui keterlibatan siswa secara aktif didalam pembelajaran. Siswa didorong untuk belajar sebagian besar melalui keterlibatan aktif mereka sendiri dengan konsep-konsep, prinsip dan guru mendorong siswa untuk memiliki pengalaman yang memungkinkan mereka menemukan prinsip untk diri mereka sendiri. Pengertian ditemukan sendiri merupakan pengertian yang betul-betul dikuasai dan mudah digunakan. Dengan menemukan sendiri maka hasil yang diperoleh setia dan tahan lama dalam ingatan. Dengan model penemua, siswa belajar berfikir analisis dan mencoba memecahkan problem yang dihadapi (Suryosubroto, 2009). Kegiatan penelitian yang telah dilaksanakan menghasilkan data hasil observasi yang berupa data keterampilan proses dan data aktivitas guru selama proses pembelajaran berlangsung.

Berdasarkan refleksi terhadap proses pembelajaran pada siklus I, maka masih terdapat hal-hal yang perlu diperhatikan sesuai dengan indikator keberhasilan yang telah ditetapkan. Adapun perbaikanperbaikan yang harus dilakukan antara lain: (1) Guru mampu meningkatkan disiplin siswa, (2) Guru harus melatih kemampuan siswa untuk mengolah dan menganalisis data. (3) Guru aktif mendampingi siswa ketika melakukan kegiatan pengumpulan data. Seluruh hasil refleksi pada siklus II jika dibandingkan dengan indikator keberhasilan yang telah ditetapkan, maka seluruh hasil yang dicapai pada siklus II ini telah melampaui semua indikator. Hasil observasi keterampilan proses siklus I dan II disajikan pada tabel 2 .

Tabel 2. Hasil observasi keterampilan proses siklus I dan siklus II

\begin{tabular}{llllll}
\hline \multirow{2}{*}{ No } & \multirow{2}{*}{ Keterampilan Proses } & Siklus I & \multicolumn{3}{l}{ Siklus II } \\
\cline { 3 - 5 } & & Nilai & Predikat & Nilai & Predikat \\
\hline 1 & Menggunakan Alat & 80 & $\mathrm{~B}$ & 87 & $\mathrm{~B}$ \\
2 & Mengumpulkan data & 89 & $\mathrm{~B}$ & 92 & $\mathrm{~A}$ \\
3 & Mengolah dan menganalisis data & 78 & $\mathrm{C}$ & 80 & $\mathrm{~B}$ \\
4 & Menyimpulkan & 85 & $\mathrm{~B}$ & 88 & $\mathrm{~B}$ \\
5 & Membuat laporan & 85 & $\mathrm{~B}$ & 90 & $\mathrm{~A}$ \\
& Rata-rata & 84 & & 87,4 & \\
\hline
\end{tabular}


Hasil observasi terhadap keterampilan proses siklus I menunjukkan bahwa keterampilan proses aspek mengolah dan menganalisis data masih kurang, karena baru mencapai 78 dengan predikat $\mathrm{C}$, sehingga diperlukan perbaikan dalam pembelajaran.

Hasil observasi siklus II menunjukkan bahwa persentase siswa yang mendapat nilai keterampilan proses $\geq 79$ adalah $100 \%$. Jumlah tersebut dikategorikan tuntas, karena seluruh siswa memperoleh nilai keterampilan proses minimal 80 (B). Peningkatan keterampilan proses dari siklus I ke siklus II dapat dilihat pada gambar 1.

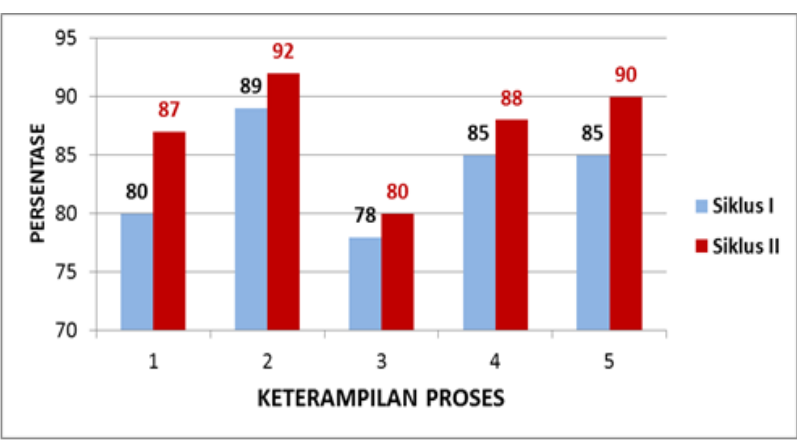

Gambar 1. Peningkatan Keterampilan Proses dari siklus I ke siklus II.

Keterangan :

1. Menggunakan alat

2. Mengumpulkan data

3. Mengolah dan menganalisis data

4. Menyimpulkan

5. Membuat Laporan

Hasil observasi aktivitas guru dalam pembelajaran dari siklus I sampai siklus II disajikan pada tabel 3.

Tabel 3. Hasil observasi aktivitas guru dalam pembelajaran dari siklus I sampai siklus II

\begin{tabular}{llllll}
\hline \multirow{2}{*}{ No } & \multirow{2}{*}{ Aspek Yang Diamati } & Siklus I & \multicolumn{3}{c}{ Siklus II } \\
\cline { 2 - 5 } & Skor & Kategori & Skor & Kategori \\
\hline 1. & Tahap Stimulasi & 3,5 & B & 4 & A \\
2. & Tahap ProblemStatement & 3 & B & 3 & B \\
3. & Tahap Data Collecting & 3,5 & B & 4 & A \\
4. Tahap Data Processing & 3 & B & 4 & A \\
5. Tahap Verification & 3 & B & 3 & B \\
6. Tahap Generalization & 3 & B & 3 & B \\
Skor Rata - rata & 3,17 & B & 3,5 & B \\
Nilai & 79,5 & B & 87,5 & B \\
\hline
\end{tabular}

Hasil rekapitulasi aktivitas guru dalam pelaksanaan pembelajaran pada siklus II menunjukkan rata-rata dari keseluruhan aspek yang diamati mempunyai kategori baik. Hasil rekapitulasi aktivitas guru dalam pelaksanaan pembelajaran pada siklus II menunjukkan bahwa guru melaksankan pembelajaran dengan menerapkan model pembelajaran penemuan (Discovery Learning) secara maksimal. Hal ini terlihat pada nilai rata-rata pencapaian aspek yang diamati sebesar $87,5 \%$ yang termasuk kategori baik .
Peningkatan aktivitas guru dalam pembelajaran dari siklus I ke siklus II disajikan pada gambar 2 .

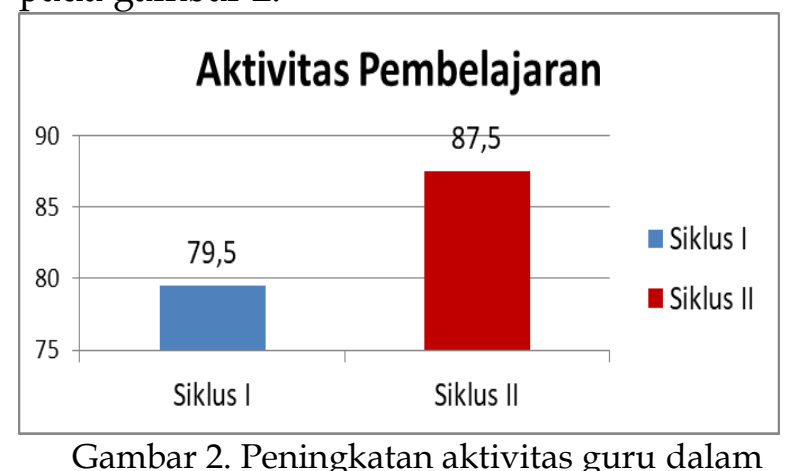

pelaksanaan pembelajaran dari siklus I ke siklus II. 
Histogram diatas menggambarkan pencapaian rata-rata nilai pada aspek pembelajaran yang diamati dari siklus I sebesar $79,5 \%$ menjadi $87,5 \%$ pada siklus II, berarti ada peningkatan 8\%. Hal ini menunjukkan peningkatan kinerja guru dalam pembelajaran.

Penelitian yang mendukung hasil ini adalah penelitian yang dilakukan oleh Ilmi et al (2012) yang menyimpulkan bahwa ada pengaruh secara signifikan penerapan metode Guided Discovery terhadap keterampilan proses sains siswa kelas X SMA Negeri 1 Teras Boyolali.

Penelitian lain berkaitan dengan penerapan model pembelajaran penemuan (Discovery Learning) adalah penelitian yang dilakukan oleh Lestari (2013) pada siswa kelas IV SD Negeri di kelurahan Kaliuntu menunjukkan bahwa terdapat perbedaan sikap ilmiah dalam pembelajaran IPA antara siswa yang mengikuti model pembelajaran Discovery Learning dengan siswa yang mengikuti model pembelajaran konvensional. Hal ini dapat dilihat dari hasil analisis data dengan menggunakan MANOVA berbantuan SPSS 17.00 for windows yang menunjukkan $\mathrm{F}=22,649 ; \mathrm{p}<0,050$.

Penelitian senada dilakukan oleh Maretasari pada siswa kelas X semester 2 SMA $\mathrm{N} 1$ Jepara. Dari hasil penelitian diperoleh peningkatan gain sikap ilmiah siswa sebesar 0,31 . Sehingga dapat disimpulkan bahwa Discovery Learning berbasis laboratorium mempunyai pengaruh terhadap sikap ilmiah siswa.

\section{Kesimpulan}

Berdasarkan hasil penelitian dan pembahasan dalam penelitian ini dapat disimpulkan bahwa Penerapan model pembelajaran penemuan (Discovery Learning) dapat meningkatkan Keterampilan Proses siswa kelas XI MIPA-3 SMAN 1 Mataram Tahun Pelajaran 2019/2020.

\section{Saran}

Penerapan model pembelajaran penemuan (Discovery Learning) dapat meningkatkan keterampilan proses siswa apabila dalam penerapannya melibatkan unsur-unsur pembelajaran yang maksimal. Disamping itu guru harus dapat mempertimbangkan keadaan internal peserta didik dalam setiap proses pembelajaran yang dilakukannya.

\section{Daftar Pustaka}

Dimyati, \& Mudjiono. (2006). Belajar dan Pembelajaran, Rineka Cipta: Jakarta.

Hosnan, M. (2014). Pendekatan Saintifik dan Kontektual dalam Pembelajaran Abad 21. Ghalia Indonesia: Bogor

Ilmi, A.N.A., Indrowati, M., Probosari, R.M. (2012). Pengaruh Penerapan Metode Pembelajaran Guided Discovery Terhadap Keterampilan Proses Sains Siswa Kelas X SMA Negeri 1 Teras Boyolali Tahun Pelajaran 2011/2012. Jurnal Pendidikan Biologi, 4(2)

Kementrian Pendidikan dan Kebudayaan Republik Indonesia. (2013). Model

Penilaian Pencapaian Kompetensi Peserta Didik Sekolah Menengah Pertama. Dirjen Pendidikan Dasar: Jakarta

Kementerian Pendidikan dan Kebudayaan, (2015). Panduan Penilaian Untuk Sekolah Menengah Atas. Direktorat Jenderal Pendidikan Dasar dan menengah: Jakarta

Lestari, D.N. (2013). Pengaruh Model Pembelajaran Inkuiri Terbimbing Terhadap Sikap Ilmiah Dan Hasil Belajar IPA. e-Journal Program Pascasarjana Universitas Pendidikan Ganesha Jurusan Pendidikan Dasar, 3(1)

Maretasari, (2012). Penerapan model pembelajaran inkuiri terbimbing Berbasis laboratorium untuk 
meningkatkan hasil Belajar dan sikap ilmiah siswa. Unnes Physics Education Journal

http://journal.unnes.ac.id/sju/index.php/upej

Sapriati, A. (2004). Pengembangan Instrumen

Penilaian Praktikum Fotosintesis. Jurnal

Pendidikan Lembaga Penelitian

Universitas Terbuka.

Slavin, R.E. (2005). Cooperative Learning.

Teori, Riset dan Praktik. Nusa Media:

Bandung

Suryosubroto, B. (2009). Proses Belajar Mengajar Di Sekolah. Rineka Cipta: Jakarta 